NBER WORKING PAPER SERIES

\title{
DOES A CURRENCY UNION AFFECT TRADE? THE TIME SERIES EVIDENCE
}

\author{
Reuven Glick \\ Andrew K. Rose \\ Working Paper 8396 \\ http://www.nber.org/papers/w8396
NATIONAL BUREAU OF ECONOMIC RESEARCH
1050 Massachusetts Avenue
Cambridge, MA 02138
July 2001

Glick is Vice President and Director of the Center for Pacific Basin Studies, Economic Research Department, Federal Reserve Bank of San Francisco. Rose is B.T. Rocca Jr. Professor of International Trade and Economic Analysis and Policy in the Haas School of Business at the University of California, Berkeley, NBER research associate and CEPR Research Fellow. We thank Sum-Yu Chiu for excellent research assistance, Juan Carlos Hallak and Patrick Honohan for catching data errors, and Jeff Frankel and Torsten Persson for encouragement and motivation. A current (PDF) version of this paper and the STATA data set used in the paper are available at http://haas.berkeley.edu/ arose. The views expressed herein are those of the authors and not necessarily those of the National Bureau of Economic Research, the Federal Reserve Bank of San Francisco, the Board of Governors of the Federal Reserve System, or their staffs.

(C) 2001 by Reuven Glick and Andrew K. Rose. All rights reserved. Short sections of text, not to exceed two paragraphs, may be quoted without explicit permission provided that full credit, including $(\subset$ notice, is given to the source. 
Does a Currency Union Affect Trade? The Time Series Evidence

Reuven Glick and Andrew K. Rose

NBER Working Paper No. 8396

July 2001

JEL No. F15, F33

\begin{abstract}
$\underline{\text { ABSTRACT }}$
Does leaving a currency union reduce international trade? We answer this question using a large annual panel data set covering 217 countries from 1948 through 1997. During this sample a large number of countries left currency unions; they experienced economically and statistically significant declines in bilateral trade, after accounting for other factors. Assuming symmetry, we estimate that a pair of countries that starts to use a common currency experiences a doubling in bilateral trade.
\end{abstract}

Reuven Glick

Federal Reserve Bank of San Francisco

101 Market Street

San Francisco, CA 94105

Tel: 415-974-3184

Fax: 415-974-2168

Email: reuven.glick@sf.frb.org
Andrew K. Rose

Haas School of Business

University of California

Berkeley, CA 94720-1900

and NBER

Tel: 510-642-6609

Fax: 510-642-4700

Email: arose@,haas.berkeley.edu 
"The direct benefits [of EMU] ... in the form of reduced transactions costs and reduced uncertainty, possibly including additional transparency in competition ... are likely to be small ..." Wyplosz (1997)

"It is clear ... that the European Commission's (1991) claim ... that the integration of product and factor markets in Europe requires a single currency has no basis in either theory or experience." Feldstein (1997)

"Contrary to widespread belief, EMY is not about lower transactions costs in cross-border operations, or about lower hedging costs, and all the other relatively petty reasons that have been invoked in its defense." Münchau Financial Times May 28, 1997.

\section{1: Introduction}

In this short paper we ask the question "What is the effect of currency union" membership on international trade?" Since an increase in trade prompted by currency union would be an unexpected benefit of European Monetary Union (EM) or dollarization, this is an interesting question to both policy-makers and academics.

Rose (2000) estimated this effect using an essentially cross-sectional approach. He used data for a large number of countries between 1970 and 1990 and found that bilateral trade was higher for a pair of countries that used the same currency than for a pair of countries with their own sovereign monies. More precisely, the coefficient (denoted $\gamma$ ) on a currency union (CU) dummy in an empirical model of bilateral trade was found to be positive and significant in both economic and statistical terms. Its value rarely fell below 1.2, implying an effect of currency union on trade of around $\left(\mathrm{e}^{1.2} \approx\right) 300 \%$. This was true even after controlling for a number of other factors, which might affect trade through the "gravity" model. The latter states that trade between a pair of countries is proportional to their combined incomes, and inversely proportional to the distance between them.

There are a number of potential issues with the cross-sectional approach. Most importantly, the policy question of interest is the (time series) question "What is the trade effect of a country joining (or leaving) a currency union?" not the cross-sectional question "How much more do countries within currency unions trade than non-members?" Other possible problems 
are econometric; for instance, pair-specific "fixed effects" may obscure the econometric estimates.

In this paper, we estimate the effect of currency unions on trade exploiting time series (as well as cross-sectional) variation. ${ }^{2}$ We use a data set that covers a large number of countries for fifty post-war years. During this sample, a large number of currency unions dissolved, allowing us to use both time series and cross-sectional variation on currency union incidence. In particular, we use the fact that over one hundred country-pairs dissolved common currency linkages during the sample. By comparing their trade before and after this regime change (holding other effects constant), we can estimate the effect of currency union membership on trade.

Reassuringly, we find that our results are basically consistent with those of Rose (2000). We find an economically and statistically significant effect of currency unions on trade using a number of different panel estimation techniques. Our estimate is that bilateral trade rises/falls by about $100 \%$ as a pair of countries forms/dissolves a currency union, ceteris paribus.

In section 2, we describe the data set and methodology that we use. Section 3 is the heart of the paper, and presents estimation results of the effect of currency union on trade. After some sensitivity analysis, the paper concludes with a brief summary.

\section{2: Methodology and Data}

\section{Gravity Methodology}

We are interested in estimating the effect of currency unions on international trade.

Towards that end, we estimate a conventional gravity model of international trade. ${ }^{3}$ We augment the model with a number of extra controls:

$$
\begin{aligned}
\ln \left(\mathrm{X}_{\mathrm{ijt}}\right) & =\beta_{0}+\beta_{1} \ln \left(\mathrm{Y}_{\mathrm{i}} \mathrm{Y}_{\mathrm{j}}\right)_{\mathrm{t}}+\beta_{2} \ln \left(\mathrm{Y}_{\mathrm{i}} \mathrm{Y}_{\mathrm{j}} / \text { Pop }_{\mathrm{i}} \mathrm{Pop}_{\mathrm{j}}\right)_{\mathrm{t}}+\beta_{3} \ln \mathrm{D}_{\mathrm{ij}}+\beta_{4} \operatorname{Lang}_{\mathrm{ij}}+\beta_{5} \text { Cont }_{\mathrm{ij}}+\beta_{6} \text { FTA }_{\mathrm{ijt}} \\
& +\beta_{7} \text { Landl }_{\mathrm{ij}}+\beta_{8} \text { Island }_{\mathrm{ij}}+\beta_{9} \ln \left(\text { Area }_{\mathrm{i}} \mathrm{Area}_{\mathrm{j}}\right)+\beta_{10} \text { ComCol }_{\mathrm{ij}}+\beta_{11} \text { CurCol }_{\mathrm{ijt}} \\
& +\beta_{12} \text { Colony }_{\mathrm{ij}}+\beta_{13} \text { ComNatij }+\gamma \mathrm{CU}_{\mathrm{ijt}}+\varepsilon_{\mathrm{ijt}}
\end{aligned}
$$


where $i$ and $j$ denotes countries, $t$ denotes time, and the variables are defined as:

- $\mathrm{X}_{\mathrm{ijt}}$ denotes the average value of real bilateral trade between $\mathrm{i}$ and $\mathrm{j}$ at time $\mathrm{t}$,

- $\mathrm{Y}$ is real GDP,

- Pop is population,

- $\quad D$ is the distance between $i$ and $j$,

- Lang is a binary variable which is unity if $i$ and $j$ have a common language,

- Cont is a binary variable which is unity if $\mathrm{i}$ and $\mathrm{j}$ share a land border,

- FTA is a binary variable which is unity if $\mathrm{i}$ and $\mathrm{j}$ belong to the same regional trade agreement,

- Landl is the number of landlocked countries in the country-pair $(0,1$, or 2$)$.

- Island is the number of island nations in the pair $(0,1$, or 2$)$,

- Area is the land mass of the country,

- ComCol is a binary variable which is unity if $\mathrm{i}$ and $\mathrm{j}$ were ever colonies after 1945 with the same colonizer,

- CurCol is a binary variable which is unity if $\mathrm{i}$ and $\mathrm{j}$ are colonies at time $\mathrm{t}$,

- Colony is a binary variable which is unity if $\mathrm{i}$ ever colonized $\mathrm{j}$ or vice versa,

- ComNat is a binary variable which is unity if $\mathrm{i}$ and $\mathrm{j}$ remained part of the same nation during the sample (e.g., France and Guadeloupe, or the UK and Bermuda),

- $\mathrm{CU}$ is a binary variable which is unity if $\mathrm{i}$ and $\mathrm{j}$ use the same currency at time $\mathrm{t}$,

- $\quad \beta$ is a vector of nuisance coefficients, and

- $\varepsilon_{\mathrm{ij}}$ represents the myriad other influences on bilateral exports, assumed to be well behaved.

The coefficient of interest to us is $\gamma$, the effect of a currency union on trade.

We estimate the model with a number of techniques below. We follow the norm in the literature by using ordinary least squares, albeit with standard errors which are robust to clustering (since pairs of countries are likely to be highly dependent across years). However, the force of the paper rests in employing a number of panel data techniques. We use both fixed and random effects estimators extensively below. We rely on the robust fixed effects "within" estimator, which essentially adds a set of country-pair specific intercepts to the equation, and thus exploits only the time series dimension of the data set around country-pair averages. 


\section{The Data Set}

Rose (2000) exploited a large data set originally developed by the United Nations, covering 186 countries from 1970 through 1990. In this paper we instead use the CD-ROM "Direction of Trade" (DoT) data set developed by the International Monetary Fund (IMF).

The DoT data set covers bilateral trade between 217 IMF country codes between 1948 and 1997 (with many gaps). Not all of the areas covered are countries in the conventional sense of the word; colonies (e.g., Bermuda), dependencies (e.g., Guernsey), territories (e.g., Guam), overseas departments (e.g., Guadeloupe), countries that gained their independence (e.g., GuineaBissau), and so forth are all included. We use the term "country" simply for convenience. (The countries are listed in Appendix 1.) Bilateral trade on FOB exports and CIF imports is recorded in American dollars; we deflate trade by the American CPI. ${ }^{4}$ We create an average value of bilateral trade between a pair of countries by averaging all of the four possible measures potentially available. $^{5}$

To this data set, we add a number of other variables that are necessary to estimate the gravity model. We add population and real GDP data (in constant dollars) from three sources. Wherever possible, we use "World Development Indicators" (taken from the World Bank's WDI 2000 CD-ROM) data. When the data are unavailable from the World Bank, we fill in missing observations with comparables from the Penn World Table Mark 5.6, and (when all else fails), from the IMF's "International Financial Statistics". 6 The series have been checked and corrected for errors.

We exploit the CIA's "World Factbook" for a number of country-specific variables. These include: latitude and longitude, land area, landlocked and island status, physically contiguous neighbors, language, colonizers, and dates of independence. ${ }^{7}$ We use these to create great-circle distance and our other controls. We obtain data from the World Trade Organization to create an indicator of regional trade agreements, and include: EEC/EC/EU; US-Israel FTA; NAFTA; CARICOM; PATCRA; ANZCERTA; and Mercosur. ${ }^{8}$

Finally, we add information on whether the pair of countries was involved in a currency union. By "currency union" we mean essentially that money was interchangeable between the two countries at a 1:1 par for an extended period of time, so that there was no need to convert prices when trading between a pair of countries. Our basic source for currency union data is the 
IMF's Schedule of Par Values and issues of the IMF's Annual Report on Exchange Rate Arrangements and Exchange Restrictions. We supplement this with information from annual copies of The Statesman's Yearbook. In the data set, about $1 \%$ of the sample covers currency unions, a proportion comparable to that in Rose, 2000). The currency unions in our data set are tabulated in Appendix 2. A number of currency unions are sufficiently integrated that trade data are unavailable; this will tend to bias our estimate of $\gamma$ downwards. ${ }^{9}$

During the sample there were 16 switches into and 130 switches out of currency unions. Some of these were related (e.g., Bermuda's switch from the pound sterling to the American dollar), and a number are cross-sectionally dependent (e.g., Equatorial Guinea entered the CFA franc zone and so joined a currency union vis-à-vis many countries simultaneously). But while we do not have 146 independent observations on regime transitions, the number is still substantive. Since we do not have many observations on currency union entries, we treat exits from and entries into currency unions symmetrically. Our techniques exploit this time series feature of the data. ${ }^{10}$

Descriptive statistics for the data set are tabulated in Table 1 for both currency unions and non-unions. Sample means for the key gravity regressors are broadly similar for currency unions and non-unions, the exception being the common language and colonial variables.

\section{3: Gravity-Based Estimates of the Effect of Currency Unions on Trade OLS Estimates}

We begin by estimating our gravity equation using conventional OLS (with a full set of year-specific intercepts added). Results are presented in Table 2.

The gravity model works well in a number of different dimensions. The model fits the data well, explaining almost two-thirds of the variation in bilateral trade flows. The gravity coefficients are economically and statistically significant with sensible interpretations. For instance, economically larger and richer countries trade more; more distant countries trade less. A common language, land border and membership in a regional trade agreement encourage trade, as does a common colonial history. The same nation coefficient is not intuitively signed but is statistically indistinguishable from zero.

The model delivers a $\gamma$ estimate of 1.41 , an estimate that is comparable to and slightly higher (in both economic and statistical significance) than that of Rose (2000). The estimate 
implies that a pair of countries that are joined by a common currency trade about four times as much with each other $\left(\mathrm{e}^{1.4} \approx 4.06\right)$, holding other things constant.

It is possible to perform extensive robustness analysis for gravity estimates like those in Table 2. For instance, we have estimated the model using only the cross-sectional aspects of the model, ignoring the time series features of our panel data set. When we do this, we find that $\gamma$ remains economically and statistically large when estimated on individual years; results are in Table 3. However, instead of pursuing that tack, we now make the most of the time series variation in our panel data set.

\section{Fixed Effects Estimates}

The fixed effect "within" estimator is the most appropriate way to exploit the panel nature of the data set without making heroic assumptions. It estimates $\gamma$ by comparing trade for a pair of countries before $\mathrm{CU}$ creation/dissolution to trade for the same pair of countries after $\mathrm{CU}$ creation/dissolution. There are only two possible drawbacks to the estimator: the impossibility of estimating time-invariant factors, and a potential lack of efficiency. Since our data set is large, we are prepared to ignore the latter problem. Since $\gamma$ can manifestly (as will be shown below) be estimated from the time series variation in currency union incidence, the former problem does not arise.

Above and beyond econometric robustness, the fixed effect estimator has one enormous advantage. Since the within estimator exploits variation over time, it answers the policy question of interest, namely the (time series) question "What is the trade effect of a country joining (or leaving) a currency union?" This can be contrasted with the cross-sectional question "How much more do countries within currency unions trade than non-members?" which was answered by Rose (2000).

Estimation results are in Table 4. We present the fixed effects estimates of $\gamma$ and a few of the key gravity coefficients in the left-hand column. For comparison, we also tabulate random effects estimates, using a generalized least squares estimator assuming Gaussian disturbances that are uncorrelated with the random (country-pair specific) effects. The "between" estimator (which essentially runs a regression on group averages) and a normal maximum likelihood estimator are also shown at the right-hand side of the table. 
The fixed effects estimate of $\gamma$ is smaller than the OLS estimates of Table 2 and 3. Since

$\mathrm{e}^{.74} \approx 2.1$, the estimate implies that leaving/joining a currency union leads bilateral trade to fall/rise by about $100 \%$. But this effect is still economically large, and statistically significant at conventional levels; the t-statistic is over thirteen. The other estimators generate even bigger estimates of $\gamma$. And while the nuisance $(\beta)$ coefficients vary between fixed and random effects, the estimate of $\gamma$ is reasonably robust.

\section{Sensitivity Analysis}

In Table 5, we provide some sensitivity analysis. We perturb our basic methodology in a number of different ways, and tabulate estimates of $\gamma$ using both fixed and random effects estimators. In particular: 1) we add a comprehensive set of year-specific controls; 2) instead of using all years of the sample, we use only the data from every fifth year; 3) we add quadratics of both output and output per capital; 4) we throw out all industrial country observations (those with IFS country codes over 200); 5) we throw out all small country observations (those with GDP $<\$ 1$ billion); 6) we throw out all poor countries (those with real GDP per capita less than $\$ 1,000) ; 7$ ) we retain only similarly-sized country-pairs (i.e., those with GDPs which differ by less than a factor of five); 8) we retain only country-pairs where bilateral trade is a small fraction (less than 10\%) of total trade for both countries; 9) we retain only pre-1974 observations; 10) we throw out all CFA-Franc observations; and 11) we throw out all ECCB observations, as well as those which involve the American dollar, the British pound sterling, or the French Franc. ${ }^{11}$

The results of Table 5 show that $\gamma$ is reasonably insensitive to a number of different perturbations in our methodology. Our fixed effects estimates lie in the relatively narrow range of $(.53,1.03)$ and are consistent economically and statistically significant throughout. They are also consistent close to the random effects estimates of $\gamma \cdot{ }^{12}$ Other estimators (such as the panel estimator tabulated in Table 2, the between and maximum likelihood estimators tabulated in Table 4) show even higher estimates. ${ }^{13}$

To summarize: a number of different panel estimators all deliver the conclusion that currency union has a strong positive effect on trade. We rely most on the fixed effects estimator since by essentially exploiting the time series variation in currency union arrangements, it is least demanding in terms of heroic econometric assumptions. Our fixed effects estimates indicate that entry into/departure from a currency union leads bilateral trade to rise/fall by about $100 \%$, 
holding a host of other features constant. This result is not only economically and statistically significant, but seems relatively robust.

\section{Caveats}

There are issues associated with the applicability of our results. Since our sample ends before EMU, most of the currency unions involved countries that were either small, poor, or both; our results may therefore be inapplicable to EMU. On the other hand, they may be highly relevant to the many small and/or poor countries considering "dollarization". Rose and van Wincoop (2001) attack these issues using a more structural approach that allows for trade diversion and multilateral spillover effects.

In addition, we treat currency unions as exogenous with respect to trade. There are a number of reasons to believe this assumption, since there is little evidence that countries have joined currency unions to increase trade. Nevertheless, some of the apparently large tradecreating effects of currency union may actually be a reflection of reverse causality. Rose (2000) and López-Córdova and Meissner (2001) provide evidence that the effect of monetary union on trade seems high even after accounting for potential endogeneity; Persson (2001) provides counter-arguments. But while we doubt the importance of this in practice, we have been unable to devise a convincing set of instrumental variables while would allow us to quantify this effect.

\section{Conclusion}

In this paper we used a large panel data set to estimate the time series effect of currency union on trade. Our data set includes annual bilateral trade between over 230 countries from 1948 through 1997. During this period of time, a number of countries joined or (mostly) left currency unions. Controlling for a host of other influences through an augmented gravity model, we find that a pair of countries which joined/left a currency union experienced a doubling in trade. This result is economically large, statistically significant, and seems insensitive to a number of perturbations in our methodology. 


\section{References}

Feldstein, Martin (1997) "The Political Economy of the European Economic and Monetary Union” Journal of Economic Perspectives.

López-Córdova, J. Ernesto and Chris Meissner (2001) "Exchange-Rate Regimes and International Trade: Evidence from the Classical Gold Standard Era" UC Berkeley mimeo.

Persson, Torsten (2001) "Currency Unions and Trade: How Large is the Treatment Effect?" forthcoming in Economic Policy.

Rose, Andrew K. (2000) “One Money, One Market: Estimating the Effect of Common Currencies on Trade" Economic Policy.

Rose, Andrew K. and Eric van Wincoop (2001) "National Money as a Barrier to Trade: The Real Case for Monetary Union” forthcoming American Economic Review.

Walsh, Brendan (2000) "The effect of a common currency on trade: Ireland before and after the sterling link" University College Dublin working paper.

Wyplosz, Charles (1997) "EMU: Why and How It Might Happen" Journal of Economic Perspectives. 
Table 1: Descriptive Statistics

\begin{tabular}{|c|c|c|}
\hline & Non-Unions & Currency Unions \\
\hline Observations & 422,987 & 4,255 \\
\hline Log Real Trade & $\begin{array}{l}10.7 \\
(3.7) \\
\end{array}$ & $\begin{array}{l}10.5 \\
(3.1) \\
\end{array}$ \\
\hline Log Distance & $\begin{array}{l}8.2 \\
(.8) \\
\end{array}$ & $\begin{array}{c}7.1 \\
(1.0)\end{array}$ \\
\hline Log product GDP & $\begin{array}{l}47.9 \\
(2.6) \\
\end{array}$ & $\begin{array}{l}44.7 \\
(3.0) \\
\end{array}$ \\
\hline Log product GDP/capita & $\begin{array}{l}16.1 \\
(1.4)\end{array}$ & $\begin{array}{l}14.4 \\
(1.6)\end{array}$ \\
\hline Common Language Dummy & $\begin{array}{c}.15 \\
(.35) \\
\end{array}$ & $\begin{array}{c}.85 \\
(.36) \\
\end{array}$ \\
\hline Land Border Dummy & $\begin{array}{c}.02 \\
(.14) \\
\end{array}$ & $\begin{array}{c}.18 \\
(.38) \\
\end{array}$ \\
\hline Regional Trade Agreement & $\begin{array}{c}.01 \\
(.08)\end{array}$ & $\begin{array}{c}.07 \\
(.26)\end{array}$ \\
\hline Number Landlocked & $\begin{array}{c}.23 \\
(.45) \\
\end{array}$ & $\begin{array}{c}.35 \\
(.57) \\
\end{array}$ \\
\hline Number Islands & $\begin{array}{c}.35 \\
(.54) \\
\end{array}$ & $\begin{array}{c}.43 \\
(.70) \\
\end{array}$ \\
\hline Log Product Land Areas & $\begin{array}{l}23.8 \\
(3.6) \\
\end{array}$ & $\begin{array}{l}23.3 \\
(4.3) \\
\end{array}$ \\
\hline Common Colonizer & $\begin{array}{c}.06 \\
(.23) \\
\end{array}$ & $\begin{array}{c}.68 \\
(.47) \\
\end{array}$ \\
\hline Current Colony & $\begin{array}{l}.002 \\
(.04) \\
\end{array}$ & $\begin{array}{c}.16 \\
(.36) \\
\end{array}$ \\
\hline Ever Colony & $\begin{array}{c}.01 \\
(.11)\end{array}$ & $\begin{array}{c}.22 \\
(.41)\end{array}$ \\
\hline Same Nation & $\begin{array}{l}.001 \\
(.02) \\
\end{array}$ & $\begin{array}{c}.08 \\
(.28) \\
\end{array}$ \\
\hline
\end{tabular}

Means, with standard deviations reported in parentheses 
Table 2: Pooled Panel OLS Gravity Estimates

\begin{tabular}{|c|c|}
\hline Currency Union & $\begin{array}{l}1.41 \\
(.13) \\
\end{array}$ \\
\hline Log Distance & $\begin{array}{l}-1.11 \\
(.02) \\
\end{array}$ \\
\hline $\begin{array}{l}\text { Log Product Real } \\
\text { GDPs }\end{array}$ & $\begin{array}{c}.93 \\
(.01)\end{array}$ \\
\hline $\begin{array}{l}\text { Log Product Real } \\
\text { GDP/capita }\end{array}$ & $\begin{array}{c}.45 \\
(.02) \\
\end{array}$ \\
\hline Common Language & $\begin{array}{c}.37 \\
(.04) \\
\end{array}$ \\
\hline $\begin{array}{l}\text { Common Land } \\
\text { Border }\end{array}$ & $\begin{array}{c}.40 \\
(.12) \\
\end{array}$ \\
\hline $\begin{array}{l}\text { Regional Trade } \\
\text { Agreement }\end{array}$ & $\begin{array}{l}1.01 \\
(.13)\end{array}$ \\
\hline Number Landlocked & $\begin{array}{l}-.15 \\
(.03) \\
\end{array}$ \\
\hline Number Islands & $\begin{array}{c}.07 \\
(.04) \\
\end{array}$ \\
\hline $\begin{array}{l}\text { Log Product Land } \\
\text { Areas }\end{array}$ & $\begin{array}{l}-.10 \\
(.01)\end{array}$ \\
\hline Common Colonizer & $\begin{array}{c}.24 \\
(.07) \\
\end{array}$ \\
\hline Current Colony & $\begin{array}{c}.77 \\
(.26) \\
\end{array}$ \\
\hline Ever Colony & $\begin{array}{l}1.25 \\
(.13) \\
\end{array}$ \\
\hline Same Nation & $\begin{array}{c}.24 \\
(1.05)\end{array}$ \\
\hline Observations & 219,558 \\
\hline $\mathbf{R}^{2}$ & .64 \\
\hline RMSE & 2.02 \\
\hline
\end{tabular}

Intercept and year controls not recorded.

Standard errors robust to country-pair clustering recorded in parentheses.

Annual data for 231 countries, 1948-1997. 
Table 3: Cross-Sectional OLS Gravity Estimates of the Currency Union Effect

\begin{tabular}{|c|c|}
\hline Year & $\begin{array}{c}\gamma \\
(\mathrm{se})\end{array}$ \\
\hline $\mathbf{1 9 5 0}$ & .98 \\
& $(.32)$ \\
\hline $\mathbf{1 9 5 5}$ & 1.05 \\
& $(.26)$ \\
\hline $\mathbf{1 9 6 0}$ & .70 \\
& $.19)$ \\
\hline $\mathbf{1 9 6 5}$ & .85 \\
& $(.15)$ \\
\hline $\mathbf{1 9 7 0}$ & 1.38 \\
& $(.21)$ \\
\hline $\mathbf{1 9 7 5}$ & 1.36 \\
& $(.23)$ \\
\hline $\mathbf{1 9 8 0}$ & 1.28 \\
& $.23)$ \\
\hline $\mathbf{1 9 8 5}$ & 1.90 \\
& $(.23)$ \\
\hline $\mathbf{1 9 9 0}$ & 2.48 \\
& $(.25)$ \\
\hline $\mathbf{1 9 9 5}$ & 1.61 \\
& $.23)$ \\
\hline
\end{tabular}

Controls not reported: distance, output, output per capita, language, land border, FTA, landlocked, islands, land area, common colonizer, current colony, ever colony, same nation, and constant.

Standard errors recorded in parentheses.

Annual data for 231 countries. 
Table 4: Pooled Panel Gravity Estimates

\begin{tabular}{|l|c|c|c|c|}
\hline & $\begin{array}{c}\text { Fixed } \\
\text { effects } \\
\text { ("within") }\end{array}$ & $\begin{array}{c}\text { Random } \\
\text { effects } \\
\text { GLS }\end{array}$ & $\begin{array}{c}\text { Between } \\
\text { Estimator }\end{array}$ & $\begin{array}{c}\text { Maximum } \\
\text { Likelihood }\end{array}$ \\
\hline Currency Union & .74 & .82 & 1.57 & .80 \\
& $(.05)$ & $(.05)$ & $(.24)$ & $(.05)$ \\
\hline Log Distance & & -1.35 & -1.42 & -1.36 \\
& & $(.03)$ & $(.03)$ & $(.04)$ \\
\hline Log Product Real & .05 & .27 & .98 & .23 \\
GDPs & $(.01)$ & $(.01)$ & $(.01)$ & $(.01)$ \\
\hline Log Product Real & .79 & .52 & .45 & .57 \\
GDP/capita & $(.01)$ & $(.01)$ & $(.02)$ & $(.01)$ \\
\hline Common Language & & .29 & .43 & .27 \\
& & $(.06)$ & $(.06)$ & $(.07)$ \\
\hline $\begin{array}{l}\text { Common Land } \\
\text { Border }\end{array}$ & & .52 & .48 & .53 \\
\hline $\mathbf{R}^{2}:$ Within & .12 & $.16)$ & $(.17)$ & $(.19)$ \\
\hline $\mathbf{R}^{2}$ : Between & .23 & .52 & .11 & \\
\hline $\mathbf{R}^{2}:$ Overall & .23 & .47 & .53 & \\
\hline $\begin{array}{l}\text { Hausman Test (p- } \\
\text { value) }\end{array}$ & & .00 & & \\
\hline
\end{tabular}

219,558 observations in 11,178 country-pair groups. Obs per group within [1,50], mean=19.6.

Intercepts not recorded. Other controls not recorded: a) regional FTA membership, b) \# landlocked; c) \# islands; d) area; e) common colonizer; f) current colony/colonizer; g) ever colony/colonizer; h) common country. Standard errors in parentheses.

Annual data for 231 countries, 1948-1997. 
Table 5: Sensitivity Analysis of the Panel Currency Union Effect

\begin{tabular}{|l|c|c|}
\hline & $\begin{array}{c}\text { Fixed } \\
\text { effects } \\
\text { ("within") }\end{array}$ & $\begin{array}{c}\text { Random } \\
\text { effects } \\
\text { GLS }\end{array}$ \\
\hline Year Controls & .67 & .67 \\
$(.05)$ & $(.05)$ \\
\hline Data at Five-Year Intervals & .87 & 1.00 \\
& $(.12)$ & $(.11)$ \\
\hline Quadratic Output Terms & .66 & .73 \\
Added & $(.05)$ & $(.05)$ \\
\hline No Industrial Countries & .79 & .87 \\
& $(.08)$ & $(.08)$ \\
\hline No Small Countries & .79 & .88 \\
& $(.06)$ & $(.06)$ \\
\hline No Poor Countries & .67 & .73 \\
& $(.08)$ & $(.08)$ \\
\hline Similarly-Size Countries & .96 & 1.05 \\
& $(.09)$ & $(.09)$ \\
\hline Countries with Unimportant & .78 & .86 \\
Bilateral Trade & $(.06)$ & $(.06)$ \\
\hline No Pre-1970 Observations & .53 & .65 \\
& $(.09)$ & $(.09)$ \\
\hline No CFA Observations & .69 & .80 \\
& $(.06)$ & $(.06)$ \\
\hline No ECCB/American & .86 & .93 \\
Dollar/French Franc/British & $(.07)$ & $(.07)$ \\
Pound Observations & & \\
\hline Controls not report & & \\
\hline
\end{tabular}

Controls not reported: distance, output, output per capita, language, land border, FTA, landlocked, islands, land area, common colonizer, current colony, ever colony, same nation, and constant.

Standard errors in parentheses.

Annual data, 1948-1997. 


\section{Appendix 1: Countries in Sample}

\begin{tabular}{|c|c|c|}
\hline Afghanistan & Djibouti & Kuwait \\
\hline Albania & Dominica & Kyrgyz Republic \\
\hline Algeria & Dominican Rep. & Lao People's Dem. Rep. \\
\hline American Samoa & Eastern Germany & Latvia \\
\hline Angola & Ecuador & Lebanon \\
\hline Anguilla & Egypt & Lesotho \\
\hline Antigua and Barbuda & El Salvador & Liberia \\
\hline Argentina & Equatorial Guinea & Libya \\
\hline Armenia & Eritrea & Lithuania \\
\hline Aruba & Estonia & Luxembourg \\
\hline Australia & Ethiopia & Macao \\
\hline Austria & Faeroe Islands & Macedonia \\
\hline Azerbaijan & Falkland Islands & Madagascar \\
\hline Bahamas & Fiji & Malawi \\
\hline Bahrain & Finland & Malaysia \\
\hline Bangladesh & France & Maldives \\
\hline Barbados & French Guiana & Mali \\
\hline Belarus & French Polynesia & Malta \\
\hline Belgium & Gabon & Martinique \\
\hline Belize & Gambia & Mauritania \\
\hline Benin & Georgia & Mauritius \\
\hline Bermuda & Germany & Mexico \\
\hline Bhutan & Ghana & Moldova \\
\hline Bolivia & Gibraltar & Mongolia \\
\hline Bosnia \& Herzegovina & Greece & Montserrat \\
\hline Botswana & Greenland & Morocco \\
\hline Brazil & Grenada & Mozambique \\
\hline Brunei Darussalam & Guadeloupe & Namibia \\
\hline Bulgaria & Guam & Nauru \\
\hline Burkina Faso & Guatemala & Nepal \\
\hline Burma (Myanmar) & Guinea & Netherlands \\
\hline Burundi & Guinea-Bissau & Netherlands Antilles \\
\hline Cambodia & Guyana & New Caledonia \\
\hline Cameroon & Haiti & New Zealand \\
\hline Canada & Honduras & Nicaragua \\
\hline Cape Verde & Hong Kong & Niger \\
\hline Cayman Islands & Hungary & Nigeria \\
\hline Central African Rep. & Iceland & Norway \\
\hline Chad & India & Oman \\
\hline Chile & Indonesia & Pakistan \\
\hline China & Iran & Panama \\
\hline Colombia & Iraq & Papua N.Guinea \\
\hline Comoros & Ireland & Paraguay \\
\hline Congo, Dem. Rep. of (Zaire) & Israel & Peru \\
\hline Congo, Rep. of & Italy & Philippines \\
\hline Costa Rica & Jamaica & Poland \\
\hline Cote D'Ivorie (Ivory Coast) & Japan & Portugal \\
\hline Croatia & Jordan & Qatar \\
\hline Cuba & Kazakhstan & Reunion \\
\hline Cyprus & Kenya & Romania \\
\hline Czech Republic & Kiribati & Russia \\
\hline Czechoslovakia & Korea, North & Rwanda \\
\hline Denmark & Korea, South (R) & Samoa \\
\hline
\end{tabular}




$\begin{array}{ll}\text { Sao Tome \& Principe } & \text { Sudan } \\ \text { Saudi Arabia } & \text { Suriname } \\ \text { Senegal } & \text { Swaziland } \\ \text { Seychelles } & \text { Sweden } \\ \text { Sierra Leone } & \text { Switzerland } \\ \text { Singapore } & \text { Syria } \\ \text { Slovak Republic } & \text { Tajikistan } \\ \text { Slovenia } & \text { Tanzania } \\ \text { Solomon Islands } & \text { Thailand } \\ \text { Somalia } & \text { Timor } \\ \text { Somaliland, British } & \text { Togo } \\ \text { South Africa } & \text { Tonga } \\ \text { Spain } & \text { Trinidad\&Tobago } \\ \text { Spanish Sahara } & \text { Tunisia } \\ \text { Sri Lanka } & \text { Turkey } \\ \text { St. Helena } & \text { Turkmenistan } \\ \text { St. Kitts\&Nevis } & \text { Tuvalu } \\ \text { St. Pierre\&Miquelon } & \text { U.S.S.R. } \\ \text { St.Lucia } & \text { Uganda } \\ \text { St.Vincent \& Gren. } & \text { Ukraine }\end{array}$

United Arab Emirates

United Kingdom

United States

Uruguay

Uzbekistan

Vanuatu

Venezuela

Vietnam

Wake Islands

Wallis \& Futuna

West Bank/Gaza Strip

Yemen Arab Rep.

Yemen, P.D.R.

Yemen, Republic Of

Yugoslavia, Fr

(Serbia/Montenegro)

Yugoslavia, Socialist Fed. Rep.

Zambia

Zimbabwe 


\section{Appendix 2: Currency Unions in Sample}

\begin{tabular}{|c|c|c|c|c|c|}
\hline \multicolumn{2}{|c|}{ Currency Union Members } & \multirow{2}{*}{$\begin{array}{l}\text { End } \\
1975\end{array}$} & \multirow{2}{*}{$\begin{array}{l}\text { Bhutan } \\
\text { Botswana }\end{array}$} & \multirow{2}{*}{$\begin{array}{l}\text { Pakistan } \\
\text { Lesotho }\end{array}$} & \multirow{2}{*}{$\begin{array}{l}1966 \\
1977\end{array}$} \\
\hline Antigua And Barbuda & Barbados & & & & \\
\hline Antigua And Barbuda & Dominica & ongoing & Botswana & Swaziland & 1977 \\
\hline Antigua And Barbuda & Grenada & ongoing & Brunei Darussalam & Malaysia & 1971 \\
\hline Antigua And Barbuda & Guyana & 1971 & Brunei Darussalam & Singapore & ongoing \\
\hline Antigua And Barbuda & Montserrat & ongoing & Burma(Myanmar) & India & 1966 \\
\hline Antigua And Barbuda & St. Kitts\&Nevis & ongoing & Burma(Myanmar) & Pakistan & 1971 \\
\hline Antigua And Barbuda & St.Lucia & ongoing & Cameroon & Benin & ongoing \\
\hline Antigua And Barbuda & St.Vincent\&Gren & ongoing & Cameroon & Burkina Faso & ongoing \\
\hline Antigua And Barbuda & Trinidad\&Tobago & 1976 & Cameroon & Central African Rep. & ongoing \\
\hline Aruba & Netherlands Antilles & ongoing & Cameroon & Chad & ongoing \\
\hline Aruba & Suriname & 1994 & Cameroon & Comoros & 1994 \\
\hline Australia & Kiribati & ongoing & Cameroon & Congo, Rep. Of & ongoing \\
\hline Australia & Nauru & ongoing & Cameroon & Cote D'ivorie (Ivory Coast) & ongoing \\
\hline Australia & Solomon Islands & 1979 & Cameroon & Equatorial Guinea & ongoing \\
\hline Australia & Tonga & 1991 & Cameroon & Gabon & ongoing \\
\hline Australia & Tuvalu & ongoing & Cameroon & Guinea & 1969 \\
\hline Bangladesh & India & 1974 & Cameroon & Guinea-Bissau & ongoing \\
\hline Barbados & Dominica & 1975 & Cameroon & Madagascar & 1982 \\
\hline Barbados & Grenada & 1975 & Cameroon & Mali & ongoing \\
\hline Barbados & Guyana & 1971 & Cameroon & Mauritania & 1974 \\
\hline Barbados & Montserrat & 1975 & Cameroon & Niger & ongoing \\
\hline Barbados & St. Kitts\&Nevis & 1975 & Cameroon & Reunion & 1976 \\
\hline Barbados & St.Lucia & 1975 & Cameroon & Senegal & ongoing \\
\hline Barbados & St.Vincent\&Gren & 1975 & Cameroon & Togo & ongoing \\
\hline Barbados & Trinidad\&Tobago & 1975 & Central African Rep. & Benin & ongoing \\
\hline Belgium & Burundi & 1964 & Central African Rep. & Burkina Faso & ongoing \\
\hline Belgium & Congo, Dem. Rep. Of (Zaire) & 1961 & Central African Rep. & Chad & ongoing \\
\hline Belgium & Rwanda & 1966 & Central African Rep. & Comoros & 1994 \\
\hline Belgium-Luxembourg & Burundi & 1964 & Central African Rep. & Congo, Rep. Of & ongoing \\
\hline Belgium-Luxembourg & Congo, Dem. Rep. Of (Zaire) & 1961 & Central African Rep. & Cote D'ivorie (Ivory Coast) & ongoing \\
\hline Belgium-Luxembourg & Rwanda & 1966 & Central African Rep. & Equatorial Guinea & ongoing \\
\hline Benin & Burkina Faso & ongoing & Central African Rep. & Gabon & ongoing \\
\hline Benin & Cote D'ivorie (Ivory Coast) & ongoing & Central African Rep. & Guinea & 1969 \\
\hline Benin & Equatorial Guinea & ongoing & Central African Rep. & Guinea-Bissau & ongoing \\
\hline Benin & Gabon & ongoing & Central African Rep. & Madagascar & 1982 \\
\hline Benin & Guinea & 1969 & Central African Rep. & Mali & ongoing \\
\hline Benin & Guinea-Bissau & ongoing & Central African Rep. & Mauritania & 1974 \\
\hline Benin & Madagascar & 1982 & Central African Rep. & Niger & ongoing \\
\hline Benin & Mali & ongoing & Central African Rep. & Reunion & 1976 \\
\hline Benin & Mauritania & 1974 & Central African Rep. & Senegal & ongoing \\
\hline Benin & Niger & ongoing & Central African Rep. & Togo & ongoing \\
\hline Benin & Reunion & 1976 & Chad & Benin & ongoing \\
\hline Benin & Senegal & ongoing & Chad & Burkina Faso & ongoing \\
\hline Benin & Togo & ongoing & Chad & Comoros & 1994 \\
\hline Bhutan & India & ongoing & Chad & Congo, Rep. Of & ongoing \\
\hline
\end{tabular}




\begin{tabular}{|c|c|c|c|c|c|}
\hline Chad & Cote D'ivorie (Ivory Coast) & ongoing & Cote D'ivorie (Ivory Coast) & Togo & ongoing \\
\hline Chad & Equatorial Guinea & ongoing & Denmark & Faeroe Islands & ongoing \\
\hline Chad & Gabon & ongoing & Denmark & Greenland & ongoing \\
\hline Chad & Guinea & 1969 & Djibouti & Benin & 1949 \\
\hline Chad & Guinea-Bissau & ongoing & Djibouti & Burkina Faso & 1949 \\
\hline Chad & Madagascar & 1982 & Djibouti & Cameroon & 1949 \\
\hline Chad & Mali & ongoing & Djibouti & Central African Rep. & 1949 \\
\hline Chad & Mauritania & 1974 & Djibouti & Chad & 1949 \\
\hline Chad & Niger & ongoing & Djibouti & Comoros & 1949 \\
\hline Chad & Reunion & 1976 & Djibouti & Congo, Rep. Of & 1949 \\
\hline Chad & Senegal & ongoing & Djibouti & Cote D'ivorie (Ivory Coast) & 1949 \\
\hline Chad & Togo & ongoing & Djibouti & Gabon & 1949 \\
\hline Comoros & Benin & 1994 & Djibouti & Guinea & 1949 \\
\hline Comoros & Burkina Faso & 1994 & Djibouti & Madagascar & 1949 \\
\hline Comoros & Congo, Rep. Of & 1994 & Djibouti & Mali & 1949 \\
\hline Comoros & Cote D'ivorie (Ivory Coast) & 1994 & Djibouti & Mauritania & 1949 \\
\hline Comoros & Equatorial Guinea & 1994 & Djibouti & Niger & 1949 \\
\hline Comoros & Gabon & 1994 & Djibouti & Reunion & 1949 \\
\hline Comoros & Guinea & 1969 & Djibouti & Senegal & 1949 \\
\hline Comoros & Madagascar & 1982 & Djibouti & Togo & 1949 \\
\hline Comoros & Mali & 1994 & Dominica & Grenada & ongoing \\
\hline Comoros & Mauritania & 1974 & Dominica & Guyana & 1971 \\
\hline Comoros & Niger & 1994 & Dominica & Montserrat & ongoing \\
\hline Comoros & Reunion & 1976 & Dominica & St. Kitts\&Nevis & ongoing \\
\hline Comoros & Senegal & 1994 & Dominica & St.Lucia & ongoing \\
\hline Comoros & Togo & 1994 & Dominica & St.Vincent\&Gren & ongoing \\
\hline Congo, Rep. Of & Benin & ongoing & Dominica & Trinidad\&Tobago & 1976 \\
\hline Congo, Rep. Of & Burkina Faso & ongoing & Equatorial Guinea & Burkina Faso & ongoing \\
\hline Congo, Rep. Of & Cote D'ivorie (Ivory Coast) & ongoing & Equatorial Guinea & Cote D'ivorie (Ivory Coast) & ongoing \\
\hline Congo, Rep. Of & Equatorial Guinea & ongoing & Equatorial Guinea & Gabon & ongoing \\
\hline Congo, Rep. Of & Gabon & ongoing & Equatorial Guinea & Guinea-Bissau & ongoing \\
\hline Congo, Rep. Of & Guinea & 1969 & Equatorial Guinea & Mali & ongoing \\
\hline Congo, Rep. Of & Guinea-Bissau & ongoing & Equatorial Guinea & Niger & ongoing \\
\hline Congo, Rep. Of & Madagascar & 1982 & Equatorial Guinea & Senegal & ongoing \\
\hline Congo, Rep. Of & Mali & ongoing & Equatorial Guinea & Togo & ongoing \\
\hline Congo, Rep. Of & Mauritania & 1974 & France & Algeria & 1969 \\
\hline Congo, Rep. Of & Niger & ongoing & France & French Guiana & ongoing \\
\hline Congo, Rep. Of & Reunion & 1976 & France & Guadeloupe & ongoing \\
\hline Congo, Rep. Of & Senegal & ongoing & France & Martinique & ongoing \\
\hline Congo, Rep. Of & Togo & ongoing & France & Morocco & 1959 \\
\hline Cote D'ivorie (Ivory Coast) & Burkina Faso & ongoing & France & Reunion & ongoing \\
\hline Cote D'ivorie (Ivory Coast) & Madagascar & 1982 & France & St. Pierre\&Miquelon & ongoing \\
\hline Cote D'ivorie (Ivory Coast) & Mali & ongoing & France & Tunisia & 1958 \\
\hline Cote D'ivorie (Ivory Coast) & Mauritania & 1974 & Gabon & Burkina Faso & ongoing \\
\hline Cote D'ivorie (Ivory Coast) & Niger & ongoing & Gabon & Cote D'ivorie (Ivory Coast) & ongoing \\
\hline Cote D'ivorie (Ivory Coast) & Reunion & 1976 & Gabon & Guinea & 1969 \\
\hline Cote D'ivorie (Ivory Coast) & Senegal & ongoing & Gabon & Guinea-Bissau & ongoing \\
\hline
\end{tabular}




\begin{tabular}{|c|c|c|c|c|c|}
\hline Gabon & Madagascar & 1982 & Madagascar & Burkina Faso & 1982 \\
\hline Gabon & Mali & ongoing & Madagascar & Mali & 1982 \\
\hline Gabon & Mauritania & 1974 & Madagascar & Mauritania & 1974 \\
\hline Gabon & Niger & ongoing & Madagascar & Niger & 1982 \\
\hline Gabon & Reunion & 1976 & Madagascar & Reunion & 1976 \\
\hline Gabon & Senegal & ongoing & Madagascar & Senegal & 1982 \\
\hline Gabon & Togo & ongoing & Madagascar & Togo & 1982 \\
\hline Gambia & Ghana & 1965 & Malawi & Zambia & 1967 \\
\hline Gambia & Nigeria & 1967 & Malawi & Zimbabwe & 1967 \\
\hline Gambia & Sierra Leone & 1965 & Malaysia & Singapore & 1971 \\
\hline Ghana & Nigeria & 1965 & Maldives & Mauritius & 1967 \\
\hline Ghana & Sierra Leone & 1965 & Maldives & Pakistan & 1971 \\
\hline Grenada & Guyana & 1971 & Mali & Burkina Faso & ongoing \\
\hline Grenada & Montserrat & ongoing & Mali & Mauritania & 1974 \\
\hline Grenada & St. Kitts\&Nevis & ongoing & Mali & Niger & ongoing \\
\hline Grenada & St.Lucia & ongoing & Mali & Reunion & 1976 \\
\hline Grenada & St.Vincent\&Gren & ongoing & Mali & Senegal & ongoing \\
\hline Grenada & Trinidad\&Tobago & 1976 & Mali & Togo & ongoing \\
\hline Guinea & Burkina Faso & 1969 & Mauritania & Burkina Faso & 1974 \\
\hline Guinea & Cote D'ivorie (Ivory Coast) & 1969 & Mauritania & Niger & 1974 \\
\hline Guinea & Madagascar & 1969 & Mauritania & Reunion & 1974 \\
\hline Guinea & Mali & 1969 & Mauritania & Senegal & 1974 \\
\hline Guinea & Mauritania & 1969 & Mauritania & Togo & 1974 \\
\hline Guinea & Niger & 1969 & Mauritius & Seychelles & 1976 \\
\hline Guinea & Reunion & 1969 & Montserrat & St. Kitts\&Nevis & ongoing \\
\hline Guinea & Senegal & 1969 & Montserrat & St.Lucia & ongoing \\
\hline Guinea & Togo & 1969 & Montserrat & St.Vincent\&Gren & ongoing \\
\hline Guinea-Bissau & Burkina Faso & ongoing & Montserrat & Trinidad\&Tobago & 1976 \\
\hline Guinea-Bissau & Cote D'ivorie (Ivory Coast) & ongoing & Netherlands Antilles & Suriname & 1994 \\
\hline Guinea-Bissau & Mali & ongoing & New Caledonia & French Polynesia & ongoing \\
\hline Guinea-Bissau & Niger & ongoing & New Caledonia & Vanuatu & 1971 \\
\hline Guinea-Bissau & Senegal & ongoing & New Caledonia & Wallis \& Futuna & ongoing \\
\hline Guinea-Bissau & Togo & ongoing & New Zealand & Samoa & 1967 \\
\hline Guyana & Montserrat & 1971 & Niger & Burkina Faso & ongoing \\
\hline Guyana & St. Kitts\&Nevis & 1971 & Niger & Reunion & 1976 \\
\hline Guyana & St.Lucia & 1971 & Niger & Senegal & ongoing \\
\hline Guyana & St.Vincent\&Gren & 1971 & Niger & Togo & ongoing \\
\hline Guyana & Trinidad\&Tobago & 1971 & Nigeria & Sierra Leone & 1965 \\
\hline India & Maldives & 1966 & Oman & India & 1970 \\
\hline India & Mauritius & 1966 & Pakistan & Mauritius & 1967 \\
\hline India & Pakistan & 1966 & Pakistan & Seychelles & 1967 \\
\hline India & Seychelles & 1966 & Portugal & Angola & 1976 \\
\hline Kenya & Somalia & 1971 & Portugal & Cape Verde & 1977 \\
\hline Kenya & Tanzania & 1978 & Portugal & Guinea-Bissau & 1977 \\
\hline Kenya & Uganda & 1978 & Portugal & Mozambique & 1977 \\
\hline Kuwait & India & 1961 & Portugal & Sao Tome \& Principe & 1977 \\
\hline Lesotho & Swaziland & ongoing & Qatar & India & 1966 \\
\hline
\end{tabular}




\begin{tabular}{|c|c|c|c|c|c|}
\hline Qatar & United Arab Emirates & ongoing & United Kingdom & Iraq & 1967 \\
\hline Reunion & Burkina Faso & 1976 & United Kingdom & Ireland & 1979 \\
\hline Reunion & Senegal & 1976 & United Kingdom & Israel & 1954 \\
\hline Reunion & Togo & 1976 & United Kingdom & Jamaica & 1969 \\
\hline Senegal & Burkina Faso & ongoing & United Kingdom & Jordan & 1967 \\
\hline Senegal & Togo & ongoing & United Kingdom & Kenya & 1967 \\
\hline Somalia & Tanzania & 1971 & United Kingdom & Kuwait & 1967 \\
\hline Somalia & Uganda & 1971 & United Kingdom & Libya & 1967 \\
\hline South Africa & Botswana & 1977 & United Kingdom & Malawi & 1971 \\
\hline South Africa & Lesotho & ongoing & United Kingdom & Malta & 1971 \\
\hline South Africa & Swaziland & ongoing & United Kingdom & New Zealand & 1967 \\
\hline Spain & Equatorial Guinea & 1969 & United Kingdom & Nigeria & 1967 \\
\hline Sri Lanka & India & 1966 & United Kingdom & Oman & 1971 \\
\hline Sri Lanka & Pakistan & 1967 & United Kingdom & Samoa & 1967 \\
\hline St. Kitts\&Nevis & St.Lucia & ongoing & United Kingdom & Sierra Leone & 1965 \\
\hline St. Kitts\&Nevis & St.Vincent\&Gren & ongoing & United Kingdom & Somalia & 1967 \\
\hline St. Kitts\&Nevis & Trinidad\&Tobago & 1976 & United Kingdom & South Africa & 1961 \\
\hline St. Pierre\&Miquelon & Benin & 1976 & United Kingdom & St. Helena & ongoing \\
\hline St. Pierre\&Miquelon & Burkina Faso & 1976 & United Kingdom & Tanzania & 1967 \\
\hline St. Pierre\&Miquelon & Cameroon & 1976 & United Kingdom & Uganda & 1967 \\
\hline St. Pierre\&Miquelon & Central African Rep. & 1976 & United Kingdom & Yemen, P.D.R. & 1972 \\
\hline St. Pierre\&Miquelon & Chad & 1976 & United Kingdom & Yemen, Republic Of & 1972 \\
\hline St. Pierre\&Miquelon & Comoros & 1976 & United Kingdom & Zambia & 1967 \\
\hline St. Pierre\&Miquelon & Congo, Rep. Of & 1976 & United Kingdom & Zimbabwe & 1967 \\
\hline St. Pierre\&Miquelon & Cote D'ivorie (Ivory Coast) & 1976 & United States & American Samoa & ongoing \\
\hline St. Pierre\&Miquelon & Djibouti & 1949 & United States & Bahamas & ongoing \\
\hline St. Pierre\&Miquelon & Gabon & 1976 & United States & Belize & 1949 \\
\hline St. Pierre\&Miquelon & Guinea & 1969 & United States & Bermuda & ongoing \\
\hline St. Pierre\&Miquelon & Madagascar & 1976 & United States & Dominican Rep. & 1985 \\
\hline St. Pierre\&Miquelon & Mali & 1976 & United States & Guam & ongoing \\
\hline St. Pierre\&Miquelon & Mauritania & 1974 & United States & Guatemala & 1986 \\
\hline St. Pierre\&Miquelon & Niger & 1976 & United States & Liberia & ongoing \\
\hline St. Pierre\&Miquelon & Reunion & 1976 & United States & Panama & ongoing \\
\hline St. Pierre\&Miquelon & Senegal & 1976 & Vanuatu & French Polynesia & 1971 \\
\hline St. Pierre\&Miquelon & Togo & 1976 & Vanuatu & Wallis \& Futuna & 1971 \\
\hline St.Lucia & St.Vincent\&Gren & ongoing & Wallis \& Futuna & French Polynesia & ongoing \\
\hline St.Lucia & Trinidad\&Tobago & 1976 & Yemen, P.D.R. & India & 1951 \\
\hline St.Vincent\&Gren & Trinidad\&Tobago & 1976 & Yemen, P.D.R. & Kenya & 1972 \\
\hline Tanzania & Uganda & 1978 & Yemen, P.D.R. & Somalia & 1971 \\
\hline Togo & Burkina Faso & ongoing & Yemen, P.D.R. & Tanzania & 1972 \\
\hline United Kingdom & Bahamas & 1966 & Yemen, P.D.R. & Uganda & 1972 \\
\hline United Kingdom & Bermuda & 1970 & Yemen, Republic Of & India & 1951 \\
\hline United Kingdom & Cyprus & 1972 & Yemen, Republic Of & Kenya & 1972 \\
\hline United Kingdom & Falkland Islands & ongoing & Yemen, Republic Of & Somalia & 1971 \\
\hline United Kingdom & Gambia & 1971 & Yemen, Republic Of & Tanzania & 1972 \\
\hline United Kingdom & Ghana & 1965 & Yemen, Republic Of & Uganda & 1972 \\
\hline United Kingdom & Gibraltar & ongoing & Zimbabwe & Zambia & 1967 \\
\hline
\end{tabular}


Appendix 3: Simple Bivariate Correlations

\begin{tabular}{|c|c|c|c|c|c|c|c|c|c|c|c|c|c|c|}
\hline & Trade & $\begin{array}{c}\text { Curr. } \\
\text { Union }\end{array}$ & Distance & GDP & GDP p/c & Lang. & Border & Regional & Landlck & Island & Area & Com Col & Cur.Col & Ever Col \\
\hline Curr. Union & .00 & & & & & & & & & & & & & \\
\hline Distance & -.17 & -.19 & & & & & & & & & & & & \\
\hline GDP & .67 & -.15 & .18 & & & & & & & & & & & \\
\hline GDP p/c & .41 & -.14 & .11 & .38 & & & & & & & & & & \\
\hline Language & -.01 & .19 & -.13 & -.18 & -.05 & & & & & & & & & \\
\hline Border & .11 & .13 & -.42 & -.02 & -.12 & .12 & & & & & & & & \\
\hline FTA & .08 & .08 & -.25 & .06 & .08 & -.10 & .08 & & & & & & & \\
\hline Landlocked & -.15 & .05 & -.09 & -.12 & -.21 & -.01 & .08 & -.05 & & & & & & \\
\hline Island & -.17 & .00 & .15 & -.30 & .20 & .10 & -.11 & .08 & -.19 & & & & & \\
\hline Area & .27 & -.01 & .10 & .57 & -.22 & -.11 & .10 & -.13 & .04 & -.51 & & & & \\
\hline Com. Colonizer & -.17 & .28 & -.16 & -.33 & -.21 & .36 & .07 & .12 & .03 & .16 & -.22 & & & \\
\hline Cur. Colony & .05 & .15 & .01 & -.01 & .01 & .07 & -.01 & -.01 & -.02 & .01 & -.03 & -.02 & & \\
\hline Ever Colony & .15 & .08 & -.02 & .08 & .06 & .19 & .03 & .00 & -.04 & -.03 & .01 & -.05 & .30 & \\
\hline Same Nation & .02 & .05 & .00 & -.01 & .02 & .03 & -.00 & -.00 & -.01 & .02 & -.03 & -.01 & .39 & .12 \\
\hline
\end{tabular}

Number of Observations $=219,558 \Rightarrow$ standard error $\approx .002$. 


\section{Endnotes}

1 We treat "common currencies", "currency unions", "monetary unions" and so forth synonymously.

${ }^{2}$ Walsh (2000) provides time series evidence on the dissolution of the Irish-British common currency.

${ }^{3}$ Gravity models have been much discussed in the literature; Rose (2000) provides references.

4 There are a few instances where only FOB imports are available; we then use them instead of CIF imports.

5 Since both exports and imports are measured by both countries, there are potentially four measured bilateral trade flows: exports from a to $b$, exports from $b$ to $a$, imports into a from $b$, and imports into $b$ from $a$.

6 The IFS-based series are calculated by converting national currency GDP figures into dollars at the current dollar exchange rate, and then dividing by the US GDP deflator.

7 The website is: http://www.odci.gov/cia/publications/factbook.

8 Since we are not primarily interested in estimating the FTA effect, we treat all FTAs as being equal.

9 These include Andorra-Spain/France; Belgium-Luxembourg; Austria-Liechtenstein; France-Morocco; ItalyVatican; and South Africa-Lesotho/Swaziland/Namibia.

10 These regime switches almost always occur before 1970, so that a time series technique was essentially not feasible for Rose's UN data set.

${ }^{11}$ We have also used different measures of exchange rate stability (e.g., not requiring that the exchange rate between the countries be $1: 1$ so long as it is extremely stable) without altering our conclusion that extreme monetary stability encourages trade.

${ }^{12}$ We have also examined the symmetry of entries into and exits from currency unions, but are stymied by the paucity of observations on currency union entries (which are outnumbered by exits by a ratio of over 8:1). When we do separate exits from entries, we find that the exit effect on trade is bigger than the entry effect, though our fixed effects and OLS estimates (but not the random effects estimate) do not reject equality of entry and exit coefficients at the .05 significance level. Nevertheless, it should be noted that exits tended to take place early in the sample while entries occurred late, so the effects of lags (as well as the number of data points) might bias the effect of entry downwards compared to the effect of entries. It would be interesting to pursue this issue using a methodology that accounts for the "interrupted spell" nature of the data, as well as the issues of (possibly non-randomly) missing data and repeated entries/exits fromcurrency unions.

13 Also, a random effects estimator corrected for AR(1) disturbances delivers an estimate of $\gamma=.73$ with a standard error of .08. 